\title{
Universiteit
}

Leiden

The Netherlands

\section{Urban youth speech styles in multilingual settings}

Dorleijn, M.; Kossmann, M.G.; Nortier, J.M.; Adamou, E.; Matras, Y.

\section{Citation}

Dorleijn, M., Kossmann, M. G., \& Nortier, J. M. (2020). Urban youth speech styles in multilingual settings. In E. Adamou \& Y. Matras (Eds.), The Routledge Handbook of Language Contact (pp. 366-384). Abingdon and New York: Routledge. doi:10.4324/9781351109154-23

Version:

License:

Downloaded from: $\quad$ https://hdl.handle.net/1887/3220762
Accepted Manuscript

Licensed under Article 25fa Copyright Act/Law (Amendment Taverne)

Note: To cite this publication please use the final published version (if applicable). 


\section{Universiteit}

Leiden

The Netherlands

\section{Urban youth speech styles in multilingual settings}

Margreet Dorleijn, Maarten Kossmann, and Jacomine Nortier

\section{Citation}

Dorleijn, M., Kossmann, M.G. \& Nortier, J.M. (2020), Urban youth speech styles in multilingual settings. In: Adamou E. \& Matras Y.

(Eds.) The Routledge Handbook of Language Contact. Abingdon and New York: Routledge. 366-382.

Version: Proof

License: Article 25fa of the Copyright Act 'Taverne Amendment' 


\section{Urban youth speech styles in multilingual settings}

Margreet Dorleijn, Maarten Kossmann, and Jacomine Nortier

\section{Introduction and defi nitions}

\subsection{General introduction and outline}

The phenomenon of urban youth language has been enjoying growing academic interest since the late 1990s. In this chapter, we will address issues of language contact related to urban youth languages, such as translanguaging and stylization. The way young people use highly creative ways to express their identities and demarcate group boundaries in urban societies in a globalizing world has attracted scholars from both linguistic, anthropological and sociological disciplines. Although migration, globalization and language contact have always existed, the extent to which these processes have developed over the past decades is undoubtedly the basis of this relatively recent academic interest.

As it stands today, around $50 \%$ of the world's population live in cities and by 2050 , the number is expected to increase to $70 \%$ ( United Nations, 2018 ). These numbers include relatively high proportions of children, teenagers and adolescents. Immense changes have taken place over the past few decades and in their search for a place in society today's young people are confronted with ethnic, linguistic, and rapidly spreading cultural varieties and mixes.

'Urban youth language' is a rather elusive phenomenon, which can manifest itself in different, and often very volatile, ways. This undoubtedly has contributed to the liveliness of the debates about preferred methodology. In this introduction, we will attempt to defi ne and demarcate the phenomenon addressed in this chapter.

Before we do so, we fi rst want to address the question why the multilingual language use of young city dwellers is particularly interesting.

$\mathrm{T}$ here is no professional or lay dispute about the fact that young people, more than older people, are involved in a dynamic process of discovering themselves and the world. They experiment with diff erent identities, and language is an important tool in their identity work. It is, at the same time, the means by which that identity is formed and negotiated in interaction with others (Eckert, 2008 ; Eckert and Wenger, 2005 ; Gal and Irvine, 1995 ; Irvine, 2001; V erschueren, 2004). As B ucholtz and Hall (2005) point out, this process 
takes place in monolingual environments as well, but they argue that the dynamics can be observed more clearly in cases where multilingual resources are being used.

$\mathrm{O}$ ver the past 50 years, urban environments have proven to be particularly favourable for the development of youth languages that employ multilingual repertoires. The reasons why non-Western European people moved to this part of the world are complex. Among them, decolonization and the need for cheap labour force, played an important role, eventually leading to a high degree of urban multilingualism. In other parts of the world, rapid urbanization, bringing together people from many diff erent linguistic backgrounds, has also provided fertile ground for the development of multilingual styles specifi c to young people.

\subsection{Defi nitions}

T he title of this chapter is Urban Youth Speech Styles (henceforth UYSS). In D orleijn, Mous and Nortier (2015), this term was proposed because it seems to cover the phenomenon that most researchers in the fi eld are interested in: styles of speech used by young people in urban areas. While youth styles are also found in monolingual communities, we will restrict our discussion in this Handbook to UYSS using multilingual inputs.

$\mathrm{W}$ e will use the term UYSS in the following way: linguistic practices involving the use of linguistic material from diff erent languages by young people in a multilingual urban environment, with a performative character, and which the speaker can control .

The defi nition that UYSS are linguistically distinctive speech styles mostly associated with urban youth entails three dimensions. First, only speech styles (or registers, Mesthrie et al., 2009) are concerned. This means that only ways of speaking are included that, for the majority of their users, are (expressive) stylistic choices that are deliberately chosen in order to convey a certain image of the speaker and/or of the way her/his message is meant to be understood socially. Second, we delimit the term to such speech styles that are largely associated with younger members of society living in cities. Finally, we delimit our term to styles that show linguistic deviations from the common norm, parts of which are conventionalized and enregistered (A gha, 2005), that is, they are relatively stable features users can choose to employ. This delimitation thus distinguishes UYSS from the broader category of urban vernaculars, which are not specifi cally youthful, and do not always have the expressive associations of UYSS. It also distinguishes it from the many expressive registers that are not necessarily associated with youth, such as English slang or French argot . The linguistic part of the delimitation leaves aside highly individual stylistic choices or play with diff erent (non-UYSS) registers that do not seem to have any conventionalization outside of some very small groups of peers.

Furthermore, by using the preceding defi nition, we exclude full-fl edged languages that were acquired as L1s. The UYSS are used 'on top of' one or more functionally unrestricted languages as an extra mode or style ( $\mathrm{N}$ ortier, 2018b ).

The delimitation as given here does by no means imply that UYSS constitute a homogeneous group that can easily be contrasted with other ways of speaking. As will be argued later, UYSS show a great diversity, both as regards their linguistic strategies and their social meaning. Our use of the term UYSS here should not be interpreted as establishing a distinct category, but in the sense of a pre-established basis for comparison, 
allowing one to answer questions like: what are the diff erences and similarities between ways of speaking occurring in contexts $\mathrm{X}$ (urban youth) and having the basic characteristics Y (partly conventionalized performative behaviour)? Being not only an analytical or descriptive category, UYSS is used here as a 'comparative concept' in the sense of H aspelmath (2010) .

Also, when considered as a comparative concept, our defi nition is not without problems. For example, one may wonder where 'being young' starts and ends. Does language use of preschool children belong to the category of UYSS? Are people in their thirties still young? Is the language use of adults who still use UYSS (maybe as a kind of youth reminiscence) included in the defi nition? (cf. Dorleijn, Mous and Nortier, 2015 for Sheng; Rampton, 2015 ). Is it viable to exclude language use that is beyond productive control of the speaker?

There are many terms in use that try to capture UYSS (see for example Cornips and Nortier, 2008). Widely used terms include multi-ethnolect (Clyne, 2000, among others), youth language ( Ziegler, 2018 ), urban dialect ( Wiese, 2012 ), youth interaction (for example D jenar, Ewing and Manns, 2018), and contemporary urban vernacular ( Rampton, 2015 ).

The choice of these labels often refl ects diff erences in approach and methodology, and researchers tend to have strong opinions about which labels not to use. Thus, multiethnolect is rejected by researchers who argue that a 'lect' term implies a (more or less focused) set of linguistic features that separates it from a standard language or other 'lects' (cf. Aarsæther et al., 2015). The general term youth languages is very broad, and could in principle also include monolingual performative and expressive language play as for example exercised in student associations (e.g., K iesling, 2001) . Equally, it might include the multilingual language use of young people for whom this multilingual use is a way to communicate eff ortlessly with peers with the same linguistic background, and not at all as a stylistic device to be used for group demarcation or identity construction (Anchimbe, 2015 , among others). The term youth interaction is even broader and refers to much more than just linguistic aspects. Terms like urban dialects, ethnolects, multi-ethnolects and contemporary urban vernacular suggest fi xed, conventionalized varieties, something that does not do justice to the dynamics of these ways of speaking. According to Eckert (2008, p. 26), 'The term ethnolect (like sociolect and the more generic dialect) refl ects a view of language as a fi xed rather than fl uid entity, and of identity as compartmentalized, allowing one to think of an ethnolect as a discrete system indexical of ethnicity alone.'

Specifi c UYSS come under a broad range of labels, names and instances of which the following are examples from within Europe: Perkerdansk (Denmark), Kebabnorsk (Norway), Rinkebysvenska (Sweden), Kiezdeutsch or Kanaksprak (Germany), Straattaal (Netherlands), Citétaal (Belgium), Verlan (France, as one of the forms of 'langue des jeunes') (see also Nortier and Dorleijn, 2013 ). Examples from outside Europe are Iscamtho (South Africa), Sheng and Engsh (Kenya), Camfranglais (Cameroon), Engligbo (Nigeria), Hong Kong Slanguage, and Walikan, Prokem and Gaul in Indonesia. Sometimes the labels have pejorative associations, as in the case of German Kanaksprak: 'The word Kanake is a highly derogatory term that has been used since roughly the 1970s to refer to visibly non-German foreigners or presumed foreigners, especially Turks' (L oentz, 2006, p. 33). Sometimes the labels are coined by outsiders and sometimes by speakers themselves. 
An example of the latter is Dutch Straattaal ('Street Language'), which was adopted by René Appel (1999) from users of the style. Moreover, whatever the exact history of such names, African UYSS are often referred to by their users under such terms, such as Nouchi in Abidjan and Sheng in Nairobi (K ouadio, 2006; Newell, 2009 ; Mazrui, 1995 ; Abdulaziz and Osinde, 1997 ).

The comparative concept UYSS implies one important essentialization: specifi c ways of speaking are presented as comparable, that is, as a coherent set of features, which can thus be contrasted with other ways of speaking within the community. Some scholars (e.g., Jaspers, 2008 ; Cornips, Jaspers and de Rooij, 2015 ) strongly reject this idea. This line of thought questions whether it makes sense to consider a specifi c UYSS an entity at all. Shouldn't we consider it just a set of more or less independent variables, each variable being put into action for diff erent reasons, producing diff erent kinds of indexicalities? Is there any reason to consider these variables as more than an arbitrary set put together by researchers? Aren't we creating categories that have no root in reality by naming such scientifi c constructs?

A full deconstruction of the notion of UYSS along these lines seems to miss the point, however. The feeling that there is something 'new' and 'other' going on in this type of language use is shared both by outside observers and by its users (see, e.g., W iese, 2011b) ; moreover, as Madsen remarks for Copenhagen UYSS, 'certain linguistic features [. . .] are perceived as belonging together and represent a certain way of speaking signalling certain social meaning' ( Madsen, 2011 , p. 275). This is also clear from the remarkable success of naming strategies, not only with scientists and outsiders, but also by users themselves.

\section{Historical overview of the study of UYSS}

In the study of UYSS a dichotomy can be observed between studies that focus on the norms and conventions that exist within a certain style/variety on the one hand, and studies that concentrate on the way in which social actions lead to - or are accompanied by - specifi c language practices on the other.

The fi rst type of studies has an overlap with 'classic' ethnolect studies such as W ölck (2002 ). Examples are Wiese's studies ( 2011a, 2011b ) which describe the German UYSS Kiezdeutsch as a German dialect in emergence.

For the second type of study, with a focus on UYSS as expressive, performative speaking styles in social action, LePage and Tabouret-Keller (1985 ) and Rampton's pioneering study Crossing ( 1995) count as important milestones. LePage and TabouretKeller (1985) introduced the notion of 'act of identity,' which turned out to be a powerful tool to describe the relation between language and identity. They claim that the language spoken by somebody and his or her identity as a speaker of this language are inseparable. Language acts are acts of identity. Rampton's seminal work ( 1995) used an anthropological, linguistic and ethnographic approach, strongly grounded in Conversation Analysis, which inspired many later studies. As is often the case when a new research fi eld opens up, there are, of course, precursors. An example of this is Hewitt (1982, 1986 ). Hewitt examined the sociolinguistic impact of the 'London Jamaican' creole used by young black Londoners on the language and culture of young Whites. His study was carried out among workingclass adolescents in two areas in South London where young white residents appropriated 
characteristics of young Jamaicans. He placed the use of black language forms in the speech of Whites fi rmly in its social and political setting.

In Scandinavia, Kotsinas was among the fi rst linguists to note a changing way of speaking among young people in Rinkeby, a multi-ethnic suburb near Stockholm in Sweden ( Kotsinas, 1988, 1992 ). The variety was also observed in other suburban areas and its users were young people with a migrant background as well as native Swedes.

Before the anthropological approach gained currency among sociolinguists studying UYSS, there were important variationist studies on language use by specifi c groups with a migrant background that were then mainly referred to as 'ethnolects.' Well-known examples are H orvath (1985) and W ölck (2002), who mainly focus on the correlation of certain phonological features with groups with a minority background. In accordance with the variationist framework, they do not elaborate explicitly on aspects such as agentivity, performativity and expressiveness.

Some recent studies also choose an explicitly variationist approach where respondents are placed in an experimental situation. The objective of studies of this type is to describe linguistic features which may be inherited during the acquisition process or are at least conventionalized. Such studies are important contributions when it comes to the - in our view central - question of what is contributed to UYSS by acquisition and socialization processes and what by agentive action (van M eel, 2016; H inskens, 2011 ).

$\mathrm{O}$ ther studies combine the quantitative description of linguistic aspects with a qualitative description of social action, e.g., Archakis and Papazachariou (2009).

\section{Critical issues and topics}

Two main strategies can be distinguished which set the UYSS apart from the languages that form their basis. The fi rst will be called here 'L2 stylization' (cf. Muysken, 2013 ), the second will be called 'paralexical insertion.'

\subsection{Linguistic strategies: L2 stylization}

L2 stylization refers to the emulation of the (perceived) way non-native speakers speak the dominant language. This deliberate use of L2 learner varieties can be considered stylizations (in the sense of C oupland, 2007), meaning that UYSS speakers are very well able to use more standard ways of speaking the dominant language (as opposed to real L2 interference), and that they only choose a restricted set of the many features associated to L2 learner varieties. Three types of L2 stylization are common in UYSS:

1 Stylizations of non-native accents;

2 Stylizations of non-native syntax;

3 I ntroduction of a restricted group of function words common in code-switching, such as utterance modifi ers ( Matras, 1998) and expressive interjections.

Stylizations of non-native accents come in two types. The fi rst type is the substitution of certain phonetic features of the dominant language that prove to be diffi cult for most L2 speakers. One may argue that the substitution of German [ç] by [J] or [6] in UYSS variants 
of German belongs to this type ( Auer, 2013; W iese, 2012 ). Such substitutions may be considered to be largely independent from the type of L2 that is imitated - similar problems may be expected for L2 speakers with diff erent L-1s, and thus one may argue that there is no specifi c L2 accent that is targeted here. Simplifi cation of this type is far from general in UYSS, and one should beware of presenting UYSS phonetics as simplifi ed versions of the non-UYSS variants. Thus, Moroccan Flavoured Dutch (cf. Nortier and Dorleijn, 2008 ), while presenting quite diff erent phonetics, maintains the full set of standard Dutch vowel distinctions ( Mourigh, forthcoming) ; this is very diff erent from Moroccan L2 accents in Dutch.

The second type of L2 stylization is inspired by the L2 accents of specifi c L-1 groups. The afore-mentioned Moroccan Flavoured Dutch is a case in point. This variety, used both by young people with a Moroccan background and by people with diff erent linguistic histories as well, features Moroccan-like intonation and syllabifi cation, as well as some other features that are typical for older Moroccan L2 speakers of Dutch. For example, it presents highly complex consonant clusters (at least on the phonetic level), such as [ $\mathrm{ks} \mathrm{x}_{\mathrm{t}} \mathrm{t}$ $\left.\mathrm{x}_{\mathrm{i}} \mathrm{h} \varepsilon \mathrm{m}\right]$ instead of autochthonous Dutch [ksextexəhem] ik zeg tegen hem 'I say to him.' This can easily be understood from Moroccan Arabic and Berber, which both allow for this kind of clusters phonetically, but is very diff erent from, for example, Turkish, another important migrant language in the Netherlands.

L2 accent stylization does not just mean talking with a particular (stereotyped) L2 accent. Moroccan Flavoured Dutch presents us with a clear example of how such stylizations can be inspired by, and still be diff erent from, L2 pronunciations and stereotypes. In many older Moroccan's L2 Dutch, /s/ is pronounced [S] in all positions of the word, a pronunciation which also belongs to the stereotype of the accent. In Moroccan Flavoured Dutch, this pronunciation is found as a stylistic variable, but here, it only takes place under the specifi c phonetic condition of clusters with sibilants followed by a continuant. Thus, /slapə/ ( slapen ) 'to sleep' can be pronounced [Jla:pə], but /ste:ts/ ( steeds) 'continually' is consistently pronounced [ste:ts] (M ourigh, 2017a). This shows that the stylization is not just an on-the-spot imitation of a stereotype, but that it is a convention that is not necessarily identical to the stereotype it is based on.

I $\mathrm{n}$ addition to phonetics, L2 stylization also concerns morphosyntax and syntax. In UYSS based on continental Germanic languages, two features of stylization are widespread. The fi rst feature is the neutralization of grammatical gender. Continental Germanic languages distinguish two or three genders with nouns, whose semantic distribution is highly erratic. Gender is mainly expressed on nominal modifi ers. Confusion between grammatical genders is common among L2 speakers, and many of them choose to neutralize genders in favour of the most frequent form. This is something also commonly found in UYSS in this part of the world ( Cheshire, Nortier and Adger, 2015 ).

I $\mathrm{n}$ the same languages, L2 speakers often use word order deviant from the norm. In continental Germanic, there exists a rule that, in main clauses, the verb occupies the second position in the clause, irrespective of the nature of the fi rst element in the clause. As this fi rst element is often the subject of the clause, it is not unexpected that L2 speakers simplify the system by using strict $\mathrm{SV}(\mathrm{O})$ word order. This means that while the dominant variety would have variation between $\mathrm{S}-\mathrm{V}$ and Adverb $-\mathrm{V}-\mathrm{S}$, L2 speakers use Adverb $-\mathrm{S}-\mathrm{V}$. 
Among UYSS, such constructions are well attested in Scandinavia and Germany (F reywald et al., 2015) . The following is an example from Berlin:

1. $a b \quad$ jetzt
zwanzig euro $\quad \begin{aligned} & \text { (Freywald et al., 2015, p. 89) } \\ & \text { (Frieg immer }\end{aligned}$

from now I get always twenty euros i nstead of standard German:

2. $\quad$ ab jetzt krieg ich immer zwanzig euro from now get

I always twenty euros

'From now on, I get always twenty euros.'

I $\mathrm{n}$ addition to phonetic and (morpho)-syntactic features, UYSS that rely strongly on L2 stylizations also feature the use of a small set of borrowed function words. Most of these are utterance modifi ers or interjections, such as wollah/vallah 'I swear!; assuredly!' in a large number of European UYSS and lan 'post-sentence tag, man' in UYSS with an important Turkish component. However, in some UYSS of this type insertion of function words that are internal to the clause also occurs (K ossmann, 2017a) , cf. the following example from Moroccan Flavoured Dutch in Gouda, where the Tarifi yt Berber indefi nite article $i z ̌ z ̌ \partial n$ is used in an otherwise Dutch sentence:

\section{3. ja, precies, als je bij $\underline{i z z z z o n}$ weg komt yes precisely}

if you at a road come

'Yes, exactly, if you arrive there at a road.' ( Mourigh, forthcoming)

It is not always easy to decide whether, in a certain situation, an L2 feature as used by a UYSS user is really a conscious choice (as implied by stylization). Many young people with a migratory background grow up with non-native L2 learner variants of the dominant language in their households, and some L2 features surfacing in their speech may not be conscious choices, but rather the eff ect of linguistic uncertainty about specifi c features of the dominant language. Thus, on the one hand some users of Moroccan Flavoured Dutch report gender neutralization as a conscious stylistic choice, using, for instance, the article $d e$ with nouns that have het in the dominant language ( $\mathrm{N}$ ortier and Dorleijn, 2008). On the other hand, in written internet discourse aiming at the dominant variety of Dutch, some Moroccan heritage young people show large-scale hypercorrection, using, for instance, the non-UYSS article het with nouns that require de (e.g., het jongen instead of de jongen 'the boy') (cf. also C ornips, 2008) .

In a number of UYSS the target of emulation does not seem to be an L2 stereotype, but rather a regional variant of the dominant language. This is the case in Multicultural London English, the phonetics of which are inspired by the Jamaican pronunciation of English ( Cheshire et al., 2011 ). Here the dynamics seem to be the same as for continental European UYSS with the diff erence that the main target of emulation was a group that already spoke English before they migrated to Europe. 
Margreet Dorleijn et al.

\subsection{Linguistic strategies: paralexical insertion}

The second main strategy in the linguistic constituency of UYSS will be called paralexical insertion. The term paralexicon has been borrowed from argot studies (Dubois et al., 2012 ; cf. also Mous, 2003 ). It refers to a large but restricted set of style-specifi c lexical items that may be used as substitutes for normal lexical items in order to attain a certain stylistic goal. This process mainly targets the lexicon. Such insertions take place into a matrix of more neutral speech. The matrix provides the grammatical grid for the utterance and most of the lexicon, while the style-specifi c lexical elements are inserted into lexical positions within this grid ( Mesthrie and Hurst, 2013 ). In general, these insertions express concepts that could also have been expressed (with diff erent expressivity) in the matrix language. The matrix of a UYSS can itself be a way of speaking involving a large amount of code-switching between several languages (M esthrie and Hurst, 2013) .

While many concepts have two instantiations - both one or several matrix forms and the paralexical form - many other concepts can only be expressed by means of the matrix language(s). The paralexical set may consist of words from foreign languages, phonologically manipulated elements from the matrix language, and matrix or foreign words with semantic changes. A European example of such a paralexical set in UYSS is Dutch Straattaal, which is characterized by a large set of words mainly taken over from Sranan Tongo, the creole language of Suriname, but expanded by words from other migratory languages and by manipulated Dutch and English items. The Straattaal paralexical set includes a wide variety of concepts somehow related to street style or otherwise important to adolescent urban life, e.g., tata 'autochthonous Dutch,' sma 'girl,' scoro 'school,' oso 'house,' pata 'shoe,' wagi 'car.'

Indonesian provides another example. It has an open pronominal system, which has multiple forms to refer to speaker and addressee. First and second singular pronouns from other languages are easily inserted ( Djenar, Ewing and Manns, 2018 ). Thus, for example, in youth interaction, an Arabic fi rst singular ana 'I' can be inserted to indicate (or emphasize) the religious (muslim) identity of the speaker. Besides, elements from other Indonesian languages are inserted through 'crossing' to play around with (ethnic or other) identities.

$\mathrm{P}$ aralexical sets do not only consist of loanwords. They also include - and in some cases predominantly consist of - words in the matrix language that have been manipulated formally (e.g., by truncation or by suffi xation, Kießling and Mous, 2004 ) or semantically. In addition to this, one often fi nds words whose etymology is fully opaque. A number of examples from Juba UYSS (which has a Juba Arabic matrix) are given in Table 19.1 ( Nakao, 2013) .

The paralexicon is not always bound to one single matrix language. In South Africa, the UYSS that are called Tsotsitaal $\mathrm{s}$ in the scientifi $\mathrm{c}$ literature consist of a single (though highly variable) set of potential insertions, which can be combined with diff erent matrix languages ( Hurst, 2015 ). Paralexical sets are thus potentially independent from the matrix language.

Mesthrie and Hurst (esp. 2013), discussing the South-African situation, make a strict separation between, on the one hand, urban varieties of the matrix language (including ways of speaking involving a lot of code-switching), and on the other hand the paralexicon. This 
means that the matrix can be quite diff erent from standard varieties but should still not be considered as specifi c to the UYSS. It also means, according to Mesthrie and Hurst, that the specifi city of paralexical UYSS is purely lexical in nature; all unexpected syntactic features would be part of the matrix. While this seems to make sense in the case of most African UYSS, it is problematic for Dutch Straattaal, where a paralexical set is combined with a small number of morphosyntactic features, esp. gender neutralization, which do not seem to be common outside UYSS contexts.

I $t$ should also be stressed that there is no obligation to use the full set of words belonging to the paralexicon when choosing to use an UYSS. That is, just a few insertions may suffi ce to reach the intended style. There are no doubt diff erences between speech communities and speech situations concerning how many (and which) insertions are needed in order for speech to be recognized as UYSS (D orleijn, Mous and Nortier, 2015 ).

U YSS with paralexicon are quite similar to the traditional European anti-languages called argot - in fact, the same defi nitions given for argot in the Dictionnaire de linguistique et des sciences du langage ( Dubois et al., 2012, pp. 48-49) would apply to South African Tsotsitaal s. The distinction between UYSS and argot may be fl uid or irrelevant in this kind of speech styles.

$\mathrm{T}$ he preceding rough division into the strategies L2 stylization and paralexical insertion should not be taken as a strict categorization of diff erent UYSS. Many UYSS combine features from one and the other process; thus, Dutch Straattaal combines a paralexicon with L2 infl uences like gender neutralization. It is, however, interesting to compare to what extent one or the other process characterize the UYSS more or less. L2 stylizations seem to be extremely common in European UYSS, while only few of them use paralexical insertion as a major strategy. In fact, the Dutch situation is interesting, as two variants coexist, Straattaal, which is largely characterized by paralexifi cation, and Moroccan Flavoured Dutch, which is a typical instance of L2 stylization. While the two can be used independently, they can also be combined. This is, in fact, quite easy, as Straattaal mainly comprises content words, while Moroccan Flavoured Dutch is rather about phonetics and about functional elements; put otherwise, Moroccan Flavoured Dutch can be used as the matrix to the insertion of Straattaal paralexicon

Table 19.1 Examples from Yuba UYSS

\begin{tabular}{|c|c|c|}
\hline Loans: & bong & 'clothes' $(<$ Bari $)$ \\
\hline Formal manipulations: & $\begin{array}{l}\text { bête } \\
\text { bonto }\end{array}$ & $\begin{array}{l}\text { 'house' (< Juba Arabic bêt }+ \text { UYSS suffi } x \\
-e)\end{array}$ \\
\hline & & 'trousers' (< Juba Arabic bontolôn ) \\
\hline
\end{tabular}

(K ossmann, 2017b) . Elsewhere in the world, L2 stylization seems to be less common than in Europe, and most UYSS are mainly (or only) characterized by paralexical insertion. 
Margreet Dorleijn et al.

\subsection{The social meaning of UYSS}

Earlier, UYSS were delimited in terms of practices as being typical for urban youth. This, of course, leaves an enormous potential for associations and indexicalities attached to UYSS. To some extent, this is amplifi ed by specifi c associations to 'urbanity.' In Europe and in North America, continents with long histories of urbanization, the adjective 'urban' is often associated with lower class urban culture, and, especially, with urban countercultures. Thus 'urban dictionaries' as can be found on the internet never concern typical city life registers such as bureaucratic language or languaging in university fraternities. On the other hand, in African and South Asian cities, which have very diff erent population dynamics from Europe and North America, 'urbanity' has a strong and (for many people) positive association with modernity and upward social mobility ( $\mathrm{N}$ ortier, 2017 ).

Most European UYSS are socially grounded in second or later generation migrants who have been using the dominant language in general society from a tender age. While many of these UYSS transcend ethnic boundaries (and have therefore been called multi-ethnolects, cf. Q uist, 2008), users often have clear ideas about which ethnicities are the core users of the style. Thus, for Dutch Straattaal Surinamese heritage youth are considered the archetypical users, while uses by other migrant youth may be accepted or not, depending on whom one asks. However, the (quite frequent) use of Straattaal by people without a migratory background is considered to be unfi tting by other Straattaal users (C ornips and de Rooij, 2013; Kossmann, 2017b ; Mourigh, 2017b ). Thus, while young people with all possible diff erent heritage backgrounds practice Straattaal, it still has a clear grounding in certain groups as opposed to others. In other European UYSS, however, ethnicity may be (or have become) less important as an indexicality of the UYSS (M adsen, 2011).

O utside Europe, and particularly in sub-Saharan Africa, it seems that many UYSS have their roots in jargons related to marginal groups, criminals, prison populations, street children, etc. As a result, some of them still have a strong gang related $\mathrm{fl}$ avour, as is the case of the different Tsotsitaal s in South Africa (cf. Mesthrie and Hurst, 2013). In other cases, the UYSS has taken a diff erent direction. For example, Nouchi in Abidjan (Ivory Coast), which is said to have developed among street children, is now commonly used among young people of all kinds of social backgrounds. According to Kube's study of language use among Abidjan lycéens (high school students), over 80\% of the interviewees said they knew Nouchi; her studies include the most prestigious elite school of the city. About one-third of the interviewees claimed they used Nouchi as their main or even exclusive choice when speaking with friends. To these users the indexicalities of Nouchi are therefore very diff erent from the anti-elite counter-cultural associations of some other UYSS. In fact, Kube's research suggests that to most of her interviewees Nouchi is just associated with age (K ube, 2005 ).

The situation of the UYSS in Nairobi is still diff erent. Sheng, which has Swahili as its matrix, is associated with youth in general, although some versions of it still imply an element of being streetwise. Engsh, on the other hand, which developed as an anti-language to Sheng, nowadays 'belongs' to educated youth ( Dorleijn, Mous and Nortier, 2015 ). African UYSS do not seem to index ethnic divisions (whether specifi c groups or more generally 'migrants'), and there is little reason to assume they have ever done so in the past. European UYSS, on the other hand, have their roots in migrant communities. However, 
recently, a number of European UYSS have been said to develop into de-ethnicized youth varieties (A uer, 2013; R ampton, 2015), which would, at least at this point, make them more similar to African UYSS. This was also attested by F reywald et al. (2011) who emphasized this point and proved it through an attitude survey.

E ven UYSS that have a counter-culture type of association are not always exclusively used to index a streetwise identity. Thus, Kossmann (2017a) argues that Moroccan Flavoured Dutch - often portrayed as a streetwise, 'aggressive' UYSS ( Nortier and Dorleijn, 2008 ) - is also used by religious, law-abiding girls in order to mark a relaxed, not-so-serious stance towards their discourse. No doubt, similar complicated networks of indexicalities are to be found in other UYSS too.

U YSS are often described as being gendered, and more commonly used among males than among females (e.g., Mesthrie and Hurst, 2013 ; Nortier, 2017 ). This seems to be correlated with indexicalities of rebelliousness that are often associated with male behaviour. In UYSS that do not have such indexicalities there is little reason to expect strongly gendered patterning, and in fact, if such patterns are found, they are not very strong. $\mathrm{N}$ ortier (2017) reports how male and female young Moroccan-Dutch people comment negatively on Moroccan girls using Straattaal. The same participants, however, use Moroccan Flavored Dutch without overt attention being paid to it. Examples from Algeria, Indonesia, and Hong Kong show that both women and men use youth varieties without the overt negative connotations known from Western Europe. Nortier (2017) suggests that this can be explained in the following way: There seems to be a gender restriction for varieties used as anti-languages (H alliday, 1976), while youth varieties that mark socially upward mobility can be used by both males and females.

\section{Methodological matters}

I n order to envisage the multi-layered character of UYSS and the problems attached to its analysis, it is useful to take recourse to Silverstein's notion of the Total Linguistic Fact . This refers to the dynamic 'mutual interaction of meaningful sign forms contextualized to situations of interested human use, mediated by the fact of cultural ideology' ( Silverstein, 1985 , p. 220). For a full understanding of UYSS it is necessary to analyze them not only at the level of linguistic forms, but also on the levels of linguistic practice and ideology and their interaction. According to Silverstein (1985, p. 221) every linguistic category 'related to our ability to refer and predicate, which, carefully examined, [is] situated at such [a] triple intersection.' Although early work on UYSS did not ignore practices and ideologies, most attention was paid to the structural linguistic dimension. Quist (2008) explicitly distinguishes a linguistic variety perspective and a level of practices and ideology. These approaches diff er methodologically; the variety approach draws on dialectology and Labovian sociolinguistics and explores linguistic features characteristic of a 'variety' or 'lect,' whilst the practice and ideologies approaches are grounded in the social constructivist paradigm within sociolinguistics and explore the ways social meaning is constructed in situated discourse ( Svendsen, 2015 ; Svendsen and Quist, 2010 ).

The diff erent layers of the Total Linguistic Fact demand diff erent methods. Thus, the level of linguistic form can be studied on the basis of recording of conversations, participant observations and even elicitation (cf. N assenstein, 2018). Usually, experimental settings 
are avoided. However, see Freywald et al. (2011), where an attitudes survey in controlled group samples serves as de facto experiment.

The most common methods for studying the level of linguistic practices are in the realm of linguistic ethnography, which typically couples conversation analysis with interviews and participant observation. In such studies, one remarks a strong reliance on the in-depth analysis of very small groups of users.

T he study of UYSS language ideology concentrates on the analysis of metacommentary. Thus, in 2017, a special issue of Applied Linguistics Review was dedicated to metalinguistic comments and communities of practice (D orleijn and Nortier, 2017 ).

T he reliance on spoken conversation as found in the large majority of UYSS studies may be slightly outdated. Nowadays, Computer Mediated Communication (CMC), especially social media, is a major factor in the development of new patterns of communication. Undoubtedly, in order to understand UYSS, written data from the Internet plays a central role. Oral and CMC modalities have their own characteristics and challenges (D orleijn and Nortier, 2012 ).

$\mathrm{T}$ he usefulness of CMC data for an ethnographic approach is undisputed (see e.g., A ndroutsopoulos, 2008, 2013 ) who has done pioneering work in this approach). Where the aim of linguistic ethnography is to establish how group boundaries are set through language, which (speech) events are ordinary and which are exceptional, CMC provides an excellent resource (see e.g., Kossmann, 2017a; Nortier, 2017 ). More debate concerns the extent to which CMC data can be put on a par with (spontaneous) oral data (see Androutsopoulos, 2006 ; Dorleijn and Verschik, 2016 ). Clearly, written CMC data are diff erent, in terms of the higher level of awareness implied in writing and should not be taken as faithful renderings of oral speech, among others because disambiguation strategies used in oral interaction (such as intonation, loudness, gaze, facial expressions, gestures) are lacking in (written) CMC. In oral communication, there is less time to refl ect or to monitor and correct than in written communication, and it is more spontaneous. CMC users can correct themselves more easily than in oral encounters. On the other hand, in CMC, authors have to rely completely on (written) language for their disambiguation strategies, which arguably may lead to the more explicit use of certain linguistic features to convey a certain identity (whereas in oral interaction cues would be given in a diff erent way, e.g., through physical appearance etc.).

In CMC the participants (authors) can play more easily with identities: for example, a middle-aged Dutch woman can pretend to be a 15-year-old Moroccan-Dutch boy if she adjusts her nickname and chooses the right words, unhindered by her physical properties.

\section{Future directions}

Most quantitative and qualitative studies of UYSS focus on particular instances that are either geographically, linguistically, or ethnically restricted - or all three at the same time. The next step would be to bring these case studies together in a comparative study. Earlier, we have identifi ed two linguistic strategies (L2 stylization and paralexical insertion) that seem to apply to most if not all UYSS hitherto described. We could call them universal strategies. Can we, if we compare all individual cases of UYSS, fi nd more universal tendencies? Is it possible to design a model which takes into account social and linguistic 
factors which can explain commonalities and diff erences? Or are UYSS indeed a loose collection of phenomena that have little in common, or are not diff erent enough from other linguistic practices to warrant a separate category? Questions like the preceding can only be answered by a large-scale meta-study.

Work on UYSS generally takes a sociolinguistic, anthropological linguistic or discourse and interaction-oriented approach (often a combination of these). However, UYSS may also provide important insights to functionalist and cognitive linguists. From these perspectives the question of 'attractiveness' of the stylistic features that speakers select can be addressed. Why are particular features selected over others? To what extent do universal mechanisms such as iconicity and economy play a role? Do these features possess a certain intrinsic/universal semiotic or emotional saliency?

F urthermore, studies that focus on the perception of UYSS through experiments such as Implicit Association Tests ( Campbell-Kibler, 2012) or Matched Guise could yield fruitful results, especially when it comes to distinguishing UYSS from related varieties.

A nother direction that has not been explored to the full (if at all) is an alignment with a language acquisition approach. While the register/style approach is dominant in the analysis of UYSS (and part of our preceding defi nition), one should not rule out that for some users the UYSS has become a neutral way of speaking. Thus, in the case of urban UYSS based on colonial languages, the 'new' variant may easily develop a wide range of usages. In such communities, children may become confronted mainly with the new variant, and acquire it as their fi rst language. This seems to be the case at least for some speakers of Nouchi in Abidjan ( Kouadio, 2006 ; Newell, 2009 ) and may be much more widespread. For much of the data discussed previously (e.g., about Sheng and Moroccan Flavoured Dutch ), it is unclear to what extent they are the result of conscious manipulation by speakers, or the unconscious eff ect of language acquisition processes. Is this determined by individual circumstances of speakers (such as aptness, amount of input, etc.) or can generalizations be made?

This brings us to one more direction which could yield fruitful insights: the historical perspective. How do UYSS change? Do dialects of UYSS develop? In all UYSS, there is much variation and a much higher degree of innovation than one usually encounters in 'mainstream' languages. It is often stated, both by speakers and by researchers, that UYSS lexicons are subject to change constantly and that discontinuity of expression is the norm. This seems to be exaggerated, though, and in fact a large number of features prove to be persistent over a relatively long time-span (cf. also Hurst, 2015 ). As an example, we may adduce the use of Sranan (Surinamese) lexicon in Dutch Straattaal, which was already observed by René Appel in 1999. Even though many Straattaal users back then and nowadays have no knowledge of Sranan itself, the large majority of the Sranan-based lexicon listed in Appel (1999) is still in use 20 years later. Only few real-time analyses of linguistic change within UYSS have been undertaken so far, but one may speculate that innovations tend to focus on certain expressive and highly frequent parts of the lexicon (like evaluative adjectives and adverbs, or expressions for potential sexual partners and the ways to interact with them), and, moreover, that it is especially the most recent introductions that are substituted by innovative forms. This may lead to the observation that things constantly change, while on the other hand a considerable number of not only lexical, but also 
grammatical and phonological features remain the same. The implication of this continuity is that UYSS are not only defi ned by their dynamics but also present linguistic substance that can be studied as (linguistically, though not necessarily socially) stable features.

\title{
6. Further reading
}

Androutsopoulos, J. (2015). Networked multilingualism: Some language practices on Facebook and their implications. International Journal of Bilingualism , 19(2), pp. 185-205.

This paper proposes the term 'networked multilingualism' and presents fi ndings from a case study to explore its implications for the theorizing of multilingualism.

Djenar, D., Ewing, M. and Manns, H. (2018). Style and intersubjectivity in youth interaction . Boston and Berlin: De Gruyter.

D jenar et al. (2018) sketch a South-East Asian perspective on (multilingual) linguistic practices of young people.

Nortier, J. and Svendsen, B.A., eds. (2015). Language youth and identity in the 21 st century. Linguistic practices across urban spaces . Cambridge: Cambridge University Press.

In this book, linguistic practices from some north-West European countries are compared to each other and practices elsewhere.

Mesthrie, R. and Hurst, E. (2013). Slang registers, code-switching and restructured urban varieties in South Africa. An analytic overview of tsotsitaals with special reference to the Cape Town variety. Journal of Pidgin and Creole Languages , 28(1), pp. 103-130.

$\mathrm{T}$ his article provides a rich overview of the features and analytical challenges presented by UYSS in South Africa.

\section{Related topics}

Processing multilingual data, social factors, borrowing, code-switching, linguistic landscape, and urban multilingualism

\author{
Abbreviations \\ CMC Computer Mediated Communication \\ L1 fi rst language \\ L2 second language \\ O object \\ S subject \\ UYSS Urban Youth Speech Styles \\ V verb
}

\section{References}

Aarsæther, F., Marzo, S., Nistov, I. and Ceuleers, E. (2015). Indexing locality: Contemporary urban vernaculars in Belgium and Norway. In: J. Nortier and B.A. Svendsen, eds., Language, youth and identity in the 21st century. Linguistic practices across urban spaces, 1st ed. Cambridge: Cambridge University Press, pp. 249-270. 
A bdulaziz, M. and Osinde, K. (1997). Sheng and Engsh: Development of mixed codes among the urban youth in Kenya. International Journal of the Sociology of Language , 125, pp. 43-63.

Agha, A. (2005). Voice, footing, enregisterment. Journal of Linguistic Anthropology, 15(1), pp. 38 59.

Anchimbe, E. (2015). Code-switching: Between identity and exclusion. In: G. Stell and K. Yakpo, eds., Code-switching between structural and sociolinguistic perspectives, 1st ed. Berlin: Walter de Gruyter, pp. 139-162.

Androutsopoulos, J. (2006). Introduction: Sociolinguistics and computermediated communication. Journal of Sociolinguistics , 10(4), pp. 419-438.

Androutsopoulos, J. (2008). Potentials and limitations of discourse-centred online ethnography. In: J. Androutsopoulos and M. Beißwenger, eds., Data and methods in computer-mediated discourse analysis.Special Issue, Language@Internet, 5, Article 9.

Androutsopoulos, J. (2013). Code-switching in computer-mediated communication. In: S.C. Herring, S.D. Stein and T. Virtanen, eds., Pragmatics of computer-mediated communication, 1st ed. Berlin, Germany and New York: De Gruyter Mouton, pp. 659-686.

A ndroutsopoulos, J. (2015). Networked multilingualism: Some language practices on Facebook and their implications. International Journal of Bilingualism , 19(2), pp. 185-205.

Appel, R. (1999). Straattaal. De mengtaal van jongeren in Amsterdam [Street language. The mixed language of Amsterdam youth]. Toegepaste Taalwetenschap in Artikelen, 62, pp. 39-55.

Archakis, A. and Papazachariou, D. (2009). On young women's prosodic construction of identity. Evidence from Greek conversational narratives. In: A. Stenström and A. Jørgensen, eds., Youngspeak in a multilingual perspective, 1st ed. Amsterdam and Philadelphia: John Benjamins, pp. 13-29.

A uer, P. (2013). Ethnische Marker im Deutschen zwischen Varietät und Stil. In: A. Depperman, ed., Das Deutsch der Migranten (Institut für Deutsche Sprache, Jahrbuch 2012), 1st ed. Berlin and Boston: De Gruyter, pp. 9-40.

Bucholtz, M. and Hall, K. (2005). Identity and interaction: A sociocultural linguistic approach. Discourse Studies , 7(4-5), pp. 585-614.

C ampbell-Kibler, K. (2012). The implicit association test and sociolinguistic meaning. Lingua , 122(7), pp. 753-763.

Cheshire, J., Kerswill, P., Fox, S. and Torgersen, E. (2011). Contact, the feature pool and the speech community: The emergence of multicultural London English. Journal of Sociolinguistics , 15(2), pp. 151-196.

Cheshire, J., Nortier, J. and Adger, D. (2015). Emerging multiethnolects in Europe. Queen Mary's Occasional Papers Advancing Linguistics , 33(27).

Clyne, M. (2000). Lingua franca and ethnolects in Europe and beyond. Sociolinguistica, 14, pp. 8389.

C ornips, L. (2008). Loosing grammatical gender in Dutch: The result of bilingual acquisition and/or an act of identity? International Journal of Bilingualism , 12(1-2), pp. 105-124.

Cornips, L., Jaspers, J. and de Rooij, V. (2015). The politics of labelling youth vernaculars in the Netherlands and Belgium. In: J. Nortier and B.A. Svendsen, eds., Language, youth and identity in the 21 st century. Linguistic practices across urban spaces, 1st ed. Cambridge: Cambridge University Press, pp. 45-69.

C ornips, L. and Nortier, J., eds. (2008). Ethnolects? The emergence of new varieties among adolescents. Special Issue of International Journal of Bilingualism, 12(1-2).

Cornips, L. and de Rooij, V. (2013). Selfi ng and othering through categories of race, place, and language among minority youths in Rotterdam, The Netherlands. In: P. Siemund, I. Gogolin, M.E. Schulz and J. Davydova, eds., Multilingualism and language diversity in urban areas. Acquisition, identities, space, education, 1st ed. Amsterdam and Philadelphia: John Benjamins, pp. 129-164. 
Coupland, N. (2007). Style: Language variation and identity . Cambridge: Cambridge University Press.

Djenar, D., Ewing, M. and Manns, H. (2018). Style and intersubjectivity in youth interaction . Boston and Berlin: De Gruyter.

Dorleijn, M., Mous, M. and Nortier, J. (2015). Urban youth speech styles in Kenya and the Netherlands. In: J. Nortier and B.A. Svendsen, eds., Language, youth and identity in the 21 st century. Linguistic practices across urban spaces, 1st ed. Cambridge: Cambridge University Press, pp. 271-289.

Dorleijn, M. and Nortier, J. (2012). Bilingualism and youth languages. In: C. Chapelle, ed., The encyclopedia of applied linguistics, 1st ed. Oxford: Wiley-Blackwell, pp. 480-487.

D orleijn, M. and Nortier, J., eds. (2017). Metalinguistic discourse on multilingual urban and youth speech styles and linguistic practices. Special Issue of Applied Linguistics Review , 10(3).

D orleijn, M. and Verschik, A., eds. (2016). Using multilingual written internet data in code-switching and language contact research. Special Issue of Journal of Language Contact , 9(1).

Dubois, J., Giacomo, M., Guespin, L. and Marcellesi, C. (2012). Le Dictionnaire de Linguistique et des Sciences du Langage . Paris: Larousse.

Eckert, P. (2008). Variation and the indexical fi eld. Journal of Sociolinguistics , 12(4), pp. 453-476.

Eckert, P. and Wenger, É. (2005). Communities of practice in sociolinguistics. Journal of Sociolinguistics , 9, pp. 582-589.

Freywald, U., Cornips, L., Ganuza, N., Nistov, I. and Opsahl, T. (2015). Beyond verb second - A Matter of novel information-structure eff ects? Evidence from Norwegian, Swedish, German and Dutch. In: J. Nortier and B.A. Svendsen, eds., Language, youth and identity in the 21st century. Linguistic practices across urban spaces, 1st ed. Cambridge: Cambridge University Press, pp. $73-$ 92.

Freywald, U., Mayr, K., Özçelik, T. and Wiese, H. (2011). Kiezdeutsch as a multiethnolect. In: F. Kern and M. Selting, eds., Ethnic styles of speaking in European metropolitan areas, 1st ed. Amsterdam and Philadelphia: John Benjamins, pp. 43-75.

G al, S. and Irvine, J. (1995). The boundaries of languages and disciplines: How ideologies construct dif-ference. Social Research, 62(4), pp. 967-1002.

Halliday, M. (1976). Anti-Languages. American Anthropologist, 78(3), pp. 570-584.

H aspelmath, M. (2010). Comparative concepts and descriptive categories in crosslinguistic studies. Language, 86(3), pp. 663-687.

H ewitt, R. (1982). White adolescent creole users and the politics of friendship. Journal of Multilingual and Multicultural Development, 3(3), pp. 217-232.

Hewitt, R. (1986). White talk Black talk: Inter-racial friendship and communication amongst adolescents . Cambridge: Cambridge University Press.

H inskens, F. (2011). Emerging Moroccan and Turkish varieties of Dutch: Ethnolects or ethnic styles? In: F. Kern and M. Selting, eds., Ethnic styles of speaking in European metropolitan areas. (Studies in Language Variation 8), 1st ed. Amsterdam and Philadelphia: John Benjamins, pp. 101129.

Horvath, B. (1985). Variation in Australian English: The sociolects of Sydney . Cambridge: Cambridge University Press.

Hurst, E. (2015). Overview of the tsotsitaals of South Africa; their diff erent base languages and common lexical core items. In: N. Nassenstein and A. Hollington, eds., Youth language practices in Africa and beyond, 1st ed. Berlin: De Gruyter Mouton, pp. 169-184.

Irvine, J. (2001). 'Style' as distinctiveness: The culture and ideology of linguistic diff erentiation. In: P. Eckert and J. Rickford. eds., Style and sociolinguistic variation, 1st ed. Cambridge: Cambridge University Press, pp. 21-43. 
Jaspers, J. (2008). Problematizing ethnolects: Naming linguistic practices in an Antwerp secondary school. International Journal of Bilingualism , 12(1-2), pp. 85-103.

Kiesling, S. (2001). Stances of whiteness and hegemony in fraternity men's discourse. Linguistic Anthropology, 11(1), pp. 101-115.

Kießling, R. and Mous, M. (2004). Urban youth languages in Africa. Anthropological Linguistics, 46(3), pp. 303-341.

K ossmann, M. (2017a). Key and the use of Moroccan function words in Dutch internet discourse. Nederlandse Taalkunde , 22(2), pp. 223-248.

K ossmann, M. (2017b). Is Dutch Straattaal a mixed multiethnolect? A Moroccan perspective. Applied Linguistics Review , 10(3).

Kotsinas, U-B. (1988). Rinkebysvenska - en dialekt. In: P. Linell, V. Adelswärd, T. Nilsson and P. Petersson, eds., Svenskans beskrivning 16, 1st ed. Linköping: Linköping University Press, pp. 264-278.

K otsinas, U.-B. (1992). Immigrant adolescents' Swedish in multicultural areas. In: C. Palmgren, K. Lövgren and G. Bolin, eds., Ethnicity in youth culture, 1st ed. Stockholm: Stockholm University, pp. 43-62.

K ouadio, J.N. (2006). Le nouchi et les rapports dioula-français. Le français en Afrique, 21, pp. 177-191.

Kube, S. (2005). Gelebte Frankophonie in der Côte d'Ivoire. Dimensionen des Sprachphänomens Nouchi und die ivorische Sprachsituation aus der Sicht Abidjaner Schüler . Münster: LIT Verlag.

LePage, R. and Tabouret-Keller, A. (1985). Acts of identity . Cambridge: Cambridge University Press.

Loentz, E. (2006). Yiddish, Kanak Sprak, Klezmer, and HipHop: Ethnolect, minority culture, multicul-turalism, and stereotype in Germany. Shofar An Interdisciplinary Journal of Jewish Studies , 25(1), pp. 33-62.

Madsen, L.M. (2011). Late modern urban youth style in interaction. In: M. Selting and F. Kern, eds., Ethnic styles of speaking in European metropolitan areas, 1 st ed. Amsterdam and Philadelphia: John Benjamins, pp. 265-290.

Matras, Y. (1998). Utterance modifi ers and universals of grammatical borrowing. Linguistics , 36(2), pp. 281-331.

Mazrui, A. (1995). Slang and code-switching: The case of Sheng in Kenya. Afrikanistische Arbeitspapiere: Schriftenreihe des Kölner Instituts für Afrikanistik , 42, pp. 168-179.

Meel, L. van. (2016). The roots of ethnolects. A sociophonological study in Amsterdam and Nijmegen . PhD. Radboud Universiteit Nijmegen.

Mesthrie, R. and Hurst, E. (2013). Slang registers, code-switching and restructured urban varieties in South Africa. An analytic overview of tsotsitaals with special reference to the Cape Town variety. Journal of Pidgin and Creole Languages , 28(1), pp. 103-130.

Mesthrie, R., Swann, J., Deumert, A. and Leap, W. (2009). Introducing sociolinguistics, 2nd ed. Amsterdam and Philadelphia: John Benjamins.

M ourigh, K. (2017a). Stance-taking through sibilant palatalisation in Gouda Moroccan Dutch. Nederlandse Taalkunde, 22(3), pp. 421-446.

Mourigh, K. (2017b). A Dutch multiethnolect? Metalinguistic commentary from Gouda. Applied Linguistics Review , 10(3).

Mourigh, K. (forthcoming). Moroccan Dutch in Gouda .

Mous, M. (2003). The linguistic properties of lexical manipulation and its relevance for Ma'a and for mixed languages in general. In: P. Bakker and Y. Matras, eds., The mixed language debate: Theoretical and empirical advances, 1st ed. Berlin: De Gruyter Mouton, pp. 209-235.

Muysken, P. (2013). Ethnolects of Dutch. In: F. Hinskens and J. Taeldeman, eds., Language and space: An international handbook of linguistic variation. Volume 3, Dutch, 1st ed. Berlin: De Gruyter Mouton, pp. 739-760. 
N akao, S. (2013). The prosody of Juba Arabic: Split prosody, morphophonology, and slang. In: M. Lafkioui, ed., African Arabic: Approaches to dialectology, 1st ed. Berlin and Boston: De Gruyter Mouton, pp. 95-120.

Nassenstein, N. (2018). 'I swear they said this': Kritische Gedanken zu afrikanischen Jugendsprachen und ihren Beschreibungspraktiken. In: A. Hollington, N. Nassenstein and A. Storch, eds., Critical youth language studies - Rethinking concepts . Special Issue of The Mouth , 3, pp. 29-63.

Newell, S. (2009). Enregistering modernity, bluffi ng criminality: How Nouchi speech reinvented (and fractured) the nation. Journal of Linguistic Anthropology, 19(2), pp. 157-184.

Nortier, J. (2017). Online metalinguistic comments and gender roles in multilingual youth speech styles \& practices among Moroccan girls and women in the Netherlands. Applied Linguistics Review , 10(3).

Nortier, J. (2018b). Youth languages. In: A. Ziegler, ed., Jugendsprachen/Youth Languages. Aktuelle Perspektiven internationaler Forschung/Current Perspectives of International Research, 1st ed. Berlin and Boston: De Gruyter, pp. 3-24.

N ortier, J. and Dorleijn, M. (2008). A Moroccan accent in Dutch: A socio-cultural style restricted to the Moroccan community? International Journal of Bilingualism , 12(1-2), pp. 125-143.

Nortier, J. and Dorleijn, M. (2013). Multi-ethnolects: Kebabnorsk, Perkerdansk, Verlan, Kanakensprache, Straattaal, etc. In: P. Bakker and Y. Matras, eds., Contact languages: A comprehensive guide, 1st ed. Boston: De Gruyter Mouton, pp. 229-271.

Nortier, J. and Svendsen, B.A., eds. (2015). Language youth and identity in the 21st century. Linguistic practices across urban spaces . Cambridge: Cambridge University Press.

Q uist, P. (2008). Sociolinguistic approaches to multiethnolect: Language variety and stylistic practice. International Journal of Bilingualism , 12(1-2), pp. 43-61.

Rampton, B. (1995). Crossing. Language \& ethnicity among adolescents . Manchester, UK: St. Jerome Publishing.

Rampton, B. (2015). Contemporary urban vernaculars. In: J. Nortier and B.A. Svendsen, eds., Language, youth and identity in the 21 st century. Linguistic practices across urban spaces, 1 st ed. Cambridge: Cambridge University Press, pp. 24-44.

S ilverstein, M. (1985). Language and the culture of gender. In: E. Mertz and R. Parmentier, eds., Semiotic mediation, 1st ed. New York: Academic Press, pp. 219-259.

S vendsen, B.A. (2015). Introduction. In: J. Nortier and B.A. Svendsen, eds., Language, youth and identity in the 21st century. Linguistic practices across urban spaces, 1st ed. Cambridge: Cambridge University Press, pp. 3-23.

Svendsen, B.A. and Quist, P. (2010). Introduction. In: P. Quist and B.A. Svendsen, eds., Multilingual urban Scandinavia: New linguistic practices, 1st ed. Bristol: Multilingual Matters, pp. xiii-xxiii.

U nited Nations. (2018). Department of economic and social aff airs: Population [online] Available at:

www.un.org/en/development/desa/population/.

V erschueren, J. (2004). Notes on the role of metapragmatic awareness in language use. In: A. Jaworski, N. Coupland and D. Galasinski, eds., Metalanguage: Social and historical perspectives. Berlin and New York: De Gruyter Mouton, pp. 53-74.

Wiese, H. (2011a). Grammatical innovation in multiethnic urban Europe: New linguistic practices among adolescents. Lingua, 119, pp. 782-806.

W iese, H. (2011b). Ein neuer urbaner Dialekt im multiethnischen Raum: Kiezdeutsch. (A new urban dialect in the multiethnic public space: Kiezdeutsch). In: D. Läpple, M. Messling and J. Trabant, eds., Stadt und Urbanität im 21. Jahrhundert, 1st ed. Berlin: Kadmos, pp. 146-161.

Wiese, H. (2012). Kiezdeutsch: ein neuer Dialekt entsteht . München: C. H. Beck. 
W ölck, W. (2002). Ethnolects - between bilingualism and urban dialect. In: Li Wei and J. Dewaele, eds., Opportunities and challenges of bilingualism, 1st ed. Berlin: De Gruyter Mouton, pp. 157170.

Ziegler, A., ed. (2018). Jugendsprachen/Youth Languages. Aktuelle Perspektiven internationaler Forschung/Current perspectives of international research . Berlin and Boston: De Gruyter.

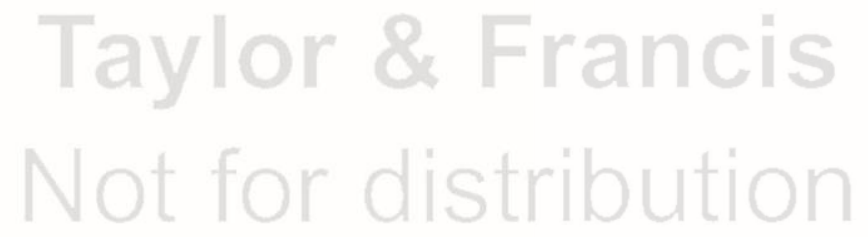

